\title{
KARAKTERISTIK MASSA AIR DI PERAIRAN BARAT DAYA PULAU SUMBA, PROVINSI NUSA TENGGARA TIMUR
}

\section{WATER MASS CHARACTERISTIC IN SOUTHWEST WATER OF SUMBA ISLAND, PROVINCE OF NUSA TENGGARA TIMUR}

\author{
Try Al Tanto ${ }^{12}$, Tri Hartanto², Mulia Purba², \& Widodo S. Pranowo \\ ${ }^{1}$ Loka Riset Sumber Daya dan Kerentanan Pesisir, BRSDMKP, KKP \\ Jl. Raya Padang-Painan Km. 16, Bungus, Padang, Sumatera Barat - 25245 \\ ${ }^{2}$ Program Studi Ilmu Kelautan, ITK, FPIK, Institut Pertanian Bogor \\ ${ }^{3}$ Pusat Riset Kelautan, BRSDMKP, KKP \\ e-mail : try_altanto@apps.ipb.ac.id/try.altanto@gmail.com
}

Diterima tanggal: 22 Maret 2019 ; diterima setelah perbaikan: 19 April 2020 ; Disetujui tanggal: 24 April 2020 DOI: http://dx.doi.org/10.15578/jkn.v15i1.7660

\begin{abstract}
ABSTRAK
Karakteristik massa air dan percampurannya dapat dipengaruhi oleh angin dan aliran air laut ke lokasi tersebut. Massa air laut terbentuk dari komposisi suhu, salinitas, dan densitas pada kedalaman tertentu. Kajian pada perairan barat daya Pulau Sumba menarik dilakukan, karena belum ada informasi sejenis, serta masih kurangnya pengelolaan. Tujuan kajian ini adalah untuk mengetahui karakteristik massa air yang menyusun perairan barat daya P. Sumba pada kondisi musim yang berbeda. Selain itu, menentukan stratifikasi massa air, struktur massa air (TS diagram), dan lapisan termoklin. Kajian massa air pada perairan barat daya P. Sumba dilakukan menggunakan data hasil reanalysis (karakteristik massa air) seluruh lautan dunia (World Ocean Atlas 2013). Pengolahan data dilakukan berupa sebaran menegak dan melintang suhu dan salinitas, serta menentukan karakteristik massa air. Kisaran suhu perairan P. Sumba musim timur tergolong rendah, SPL berkisar 26,4 - 26,49 ${ }^{\circ} \mathrm{C}$ dan secara umum dari permukaan hingga dasar dengan rentang suhu $26,49-3,4{ }^{\circ} \mathrm{C}$. Lapisan termoklin terjadi pada kedalaman 59,67 - 259,38 $\mathrm{m}$ dengan kisaran suhu $25,13-12,2{ }^{\circ} \mathrm{C}$. Kisaran salinitas permukaan laut dari pantai menuju laut lepas sebesar 34,05 - 34,11 psu, dan nilai salinitas secara menegak adalah 34,05 - 34,70 psu, salinitas maksimum terjadi pada perairan laut lepas, terjadi pada kedalaman dekat termoklin. Berbeda kondisi pada musim barat, SPL lebih hangat berkisar $27,89-29,04{ }^{\circ} \mathrm{C}$ dan lapisan tercampur lebih tipis $(<50 \mathrm{~m})$, serta lapisan termoklin terjadi pada kedalaman 45,60 - 234,89 m. Kisaran salinitas perairan juga sedikit berbeda (lebih tinggi) dengan rataan bulanan sebesar 34,52 - 34,61 psu. Pergerakan massa air permukaan pada perairan P. Sumba diperkirakan akibat angin muson . Karakteristik massa air yang terdapat ada perairan P. Sumba diperkirakan dipengaruhi oleh jenis North Pacific Subtropical Water ya ng bertransformasi mejadi jenis ITW, terjadi dekat lapisan termoklin dengan salinitas $34,55-34,7 \mathrm{psu}$, suhu $12-15^{\circ} \mathrm{C}$, dan densitas 25,5 - 26. Pada lapisan bagian bawah lapisan termoklin diduga terdapat massa air Indonesian Intermediate Water (IIW), dengan salinitas 34,6 - 34,7 psu, suhu $3-7^{\circ} \mathrm{C}$, dan densitas 27 - 27,7.
\end{abstract}

Kata kunci: suhu, salinitas, diagram T-S, karakteristik massa air, stratifikasi massa air, Pulau Sumba.

\section{ABSTRACT}

The haracteristic of water masses and their mixing in a water sea can be influenced by wind and sea water flow. Seawater mass can make from temperature, salinity, and density on some depth. The study on the southwestern water of Sumba Island was interesting because there wasn't such information, and there was still a lack of management. The aim was to find out the characteristics of the water mass that makes up the water of Southwest Sumba Island in different seasonal. In addition, it determines stratification of water mass, water mass structure, and thermocline layer. The study using reanalysis (characteristic of water masses) world ocean, data processing be done as upright and transverse distribution of sea temperature and salinity, and mass water characteristics also. Temperature values were low at the east season, SST of $26.4-26.49{ }^{\circ} \mathrm{C}$ and generally was $26.49-3.40{ }^{\circ} \mathrm{C}$. Thermocline layer be found at depth of 59.67 - $259.38 \mathrm{~m}$ with temperature values $25.13-12.2^{\circ} \mathrm{C}$. Salinity on surface water was 34.05 - $34.11 \mathrm{psu}$, and salinity values until the deep was 34.05 - 34.70 psu, maximum salinity values happened at offshore water, especially at thermocline layer. Different at the west season, SST highest was 
$27.89-29.04^{\circ} \mathrm{C}$ and mixed layer been thin $(<50 \mathrm{~m})$, and thermocline at $45.60-234.89 \mathrm{~m}$. Salinity distributions different also, monthly average was 34.52 - 34.61 psu. Movement of surface water mass was caused the monsoon wind. Characteristic of water masses of Sumba Island water were estimated to be influenced by the type of North Pacific Subtropical Water that was transformed into ITW, salinity 34.55 - 34.7 psu, temperature 12 - 15 ${ }^{\circ} \mathrm{C}$, and density 25.5 - 26, arround thermocline layer. In the lower layer of the thermocline it was suspected that there was a water masses of Indonesian Intermediate Water, salinity $34.6-34.7 \mathrm{psu}$, temperature $3-7^{\circ} \mathrm{C}$, and density 27 - 27.7.

Keywords: temperature, salinity, T-S diagram, water masses characteritic, water stratification, Sumba Island.

\section{PENDAHULUAN}

Pengetahuan tentang karakteristik massa air laut penting untuk menentukan jenis massa air yang menyusun dan melewati suatu perairan laut, baik secara vertikal dan horizontal (Kaharuddin, 2013). Secara vertikal, massa air memiliki lapisan-lapisan yang terbentuk dengan komposisi properti fisik seperti temperatur, salinitas, densitas, dan tekanan. Fenomena pelapisan massa air akan mempengaruhi kestabilan massa air tersebut (Pond \& Pickard 1983). Suhu perairan saat musim timur lebih rendah bila dibandingkan saat musim barat (Siregar et al. 2017). Kisaran suhu yang rendah tersebut $\left(<27^{\circ} \mathrm{C}\right)$, saat musim timur ini ditandai dengan terjadinya upwelling di perairan selatan Pulau Jawa (Qu et al., 2005). Perairan dekat pesisir pantai, nilai SPL lebih rendah dari pada perairan laut lepas karena kejadian upwelling (Purba, 2007). Pola distribusi SPL di Indonesia dapat dipengaruhi oleh kondisi Perairan Pasifik dan Samudera Hindia (Gaol et al., 2014). Arus Katulistiwa Selatan (AKS) di Samudra Hindia umumnya mengalir ke arah barat. Pada musim timur, angin muson tenggara membuat AKS semakin melebar ke utara bergerak sepanjang pantai selatan Jawa - Bali - Sumbawa kemudian memaksanya berbelok ke arah barat daya. Saat itu akibat angin muson tenggara, arus permukaan membawa massa air permukaan keluar menjauhi pantai selatan Jawa - Bali - Sumbawa akibatnya terjadi kekosongan di sekitar pantai selatan Jawa sehingga terjadi upwelling yang biasa terjadi mulai bulan Mei dan berakhir bulan Oktober (Wyrtki, 1962; Purba, 2007; Gaol et al., 2014).

Pencampuran massa air dan pergerakan massa air di laut, dapat berasal dari pergerakan angin dan arus laut. Angin dapat meningkatkan kejadian arus laut, saat angin bertiup energi ditransformasikan dari angin ke permukaan laut (Aldrian, 2008). Selain itu, dalam pencampuran massa air di laut, angin hanya bisa melakukan pada lapisan permukaan. Pengaruh angin dalam pengadukan lapisan permukaan menjadikan lapisan yang teraduk tersebut menjadi homogen
(Suhana et al., 2018). Lapisan tercampur merupakan lapisan yang memiliki nilai suhu hampir seragam dan lebih tinggi dari pada lapisan lainnya (Suteja et al., 2015). Sebagian besar pencampuran dan sirkulasi massa air lebih besar dipengaruhi oleh arus laut.

Di Indonesia bagian timur, Arus Lintas Indonesia (ARLINDO) mengontrol sebaran menegak massa air utama (Wijaya et al., 2011; Siregar et al. 2017). Terdapat beberapa pintu masuk ARLINDO dari Samudera Pasifik menuju Samudera Hindia, salah satunya dari Laut Flores menuju Laut Banda, yang merupakan percabangan ARLINDO sebelum memasuki Selat Lombok. Jalur yang dilewati ARLINDO dari Laut Banda ini juga terdapat beberapa pintu masuk, salah satunya di antrara P. Alor dan P. Timor atau melalui Selat Ombai menuju Laut Sawu dan perairan P. Sumba yang berlanjut hingga Samudera Hindia (Hasanudin, 1998). Selain itu juga terdapat pintu masukARLINDO melalui Laut Maluku, melewati Laut Seram hingga Laut Banda (Ilahude \& Gordon 1994; Hasanudin, 1998). Laut Halmahera juga merupakan salah satu pintu masuk ARLINDO, yang di bawa oleh New Guinea Coastal Current, kemudian mengalir ke Laut Seram dan Cekungan Aru. Perairan Selat Lombok merupakan salah satu wilayah perairan yang dilalui aliran keluar ARLINDO dari Samudera Pasifik menuju Samudera Hindia. Aliran yang terjadi tersebut melewati Selat Ombai dari pintu masuk Selat Makassar, serta aliran dari Laut Halmahera, Laut Seram, Laut Banda, hingga keluar di Laut Timor (Aken et al., 1988). Kondisi ini akan memiliki dampak besar pada pencampuran dari massa air di sekitarnya. Lokasi kajian di perairan P. Sumba cukup dekat untuk lintasan ARLINDO, tentunya akan dapat dilihat seberapa besar pengaruh dari aliran tersebut.

Tujuan dilakukan kajian ini adalah untuk mengetahui karakteristik massa air yang menyusun perairan barat daya P. Sumba pada kondisi musim yang berbeda (musim timur dan barat). Selain itu, menentukan stratifikasi massa air, struktur massa air (TS diagram), dan lapisan termoklin. 


\section{BAHAN DAN METODE}

Kajian terkait dengan karakteristik massa air dan lapisan termoklin dilakukan pada perairan P. Sumba NTT (Gambar 1). Waktu kajian dilakukan pada kondisi musim yang berbeda, yaitu musim timur (2013) dan musim barat (2013), sehingga dapat memberi gambaran kondisi parameter suhu dan salinitas pada perbedaan musim tersebut. Titik-titik stasiun data CTD yang diambil sebanyak 4 titik berada pada bagian barat daya P. Sumba, tersebar dari bagian terdekat dengan pantai hingga menuju bagian laut lepas. Posisi geografis dari titik stasiun yang diambil adalah ST $1\left(119,5^{\circ} \mathrm{BT}\right.$ dan $\left.10,5^{\circ} \mathrm{LS}\right), \mathrm{ST} 2\left(118,5^{\circ} \mathrm{BT}\right.$ dan $\left.11,5^{\circ} \mathrm{LS}\right)$, ST $3\left(118,5^{\circ} \mathrm{BT}\right.$ dan $12,5^{\circ} \mathrm{LS}$, dan ST $4\left(117,5^{\circ} \mathrm{BT}\right.$ dan $\left.13,5^{\circ} \mathrm{LS}\right)$. Pengambilan titik sampel CTD yang dilakukan tersebut dapat memberikan gambaran sebaran kondisi karakteristik massa air yang diuji tersebut dari titik terdekat dengan pantai hingga paling jauh.

Data diperoleh dari ([ODV] Ocean Data View 2013), sifat data yang diperoleh adalah data hasil reanalysis (analisis kembali) dari data pengukuran alat Condutivity Temperature Depth (CTD) selama rentang waktu tahun 1955-2012. Resolusi spasial data yang digunakan sebesar $1^{\circ} \times 1^{\circ}$, menggunakan analisis bulanan (monthly). Dalam hal ini, data yang digunakan dalam analisis adalah saat musim timur (bulan Agustus) dan musim barat (bulan Februari), dengan menyertakan perbandingan dengan data reanalysis tahun 2009 (ODV 2009) pada musim dan bulan yang sama. Resolusi vertikal data yang tersedia tersebut berdasarkan kedalaman standar, yaitu interval $5 \mathrm{~m}$ untuk kedalaman $0-100 \mathrm{~m}$, interval $25 \mathrm{~m}$ untuk kedalaman 125 - $500 \mathrm{~m}$, interval $50 \mathrm{~m}$ untuk rentang kedalaman $550-1500 \mathrm{~m}$.

Data yang dipakai berupa karakteristik massa air dari data suhu, salinitas, dan tekanan (kedalaman). Untuk melihat pengaruh dari angin, juga digunakan data angin selama 5 tahun $(2011$ - 2015) diperoleh dari ECMWF (Eropean Centre For Medium-Range Weather Forcasts, 2019). Pengolahan data dilakukan untuk memperoleh sebaran menegak dan melintang dari masing-masing parameter (suhu dan salinitas), serta menduga asal usul massa air dari diagram T-S. Dari data suhu, salinitas, dan tekanan (kedalaman) dapat diperoleh data densitas dan karakteristik massa air. Selain itu juga menentukan karakteristik lapisan termoklin tiap titik pengamatan pada musim berbeda tersebut.

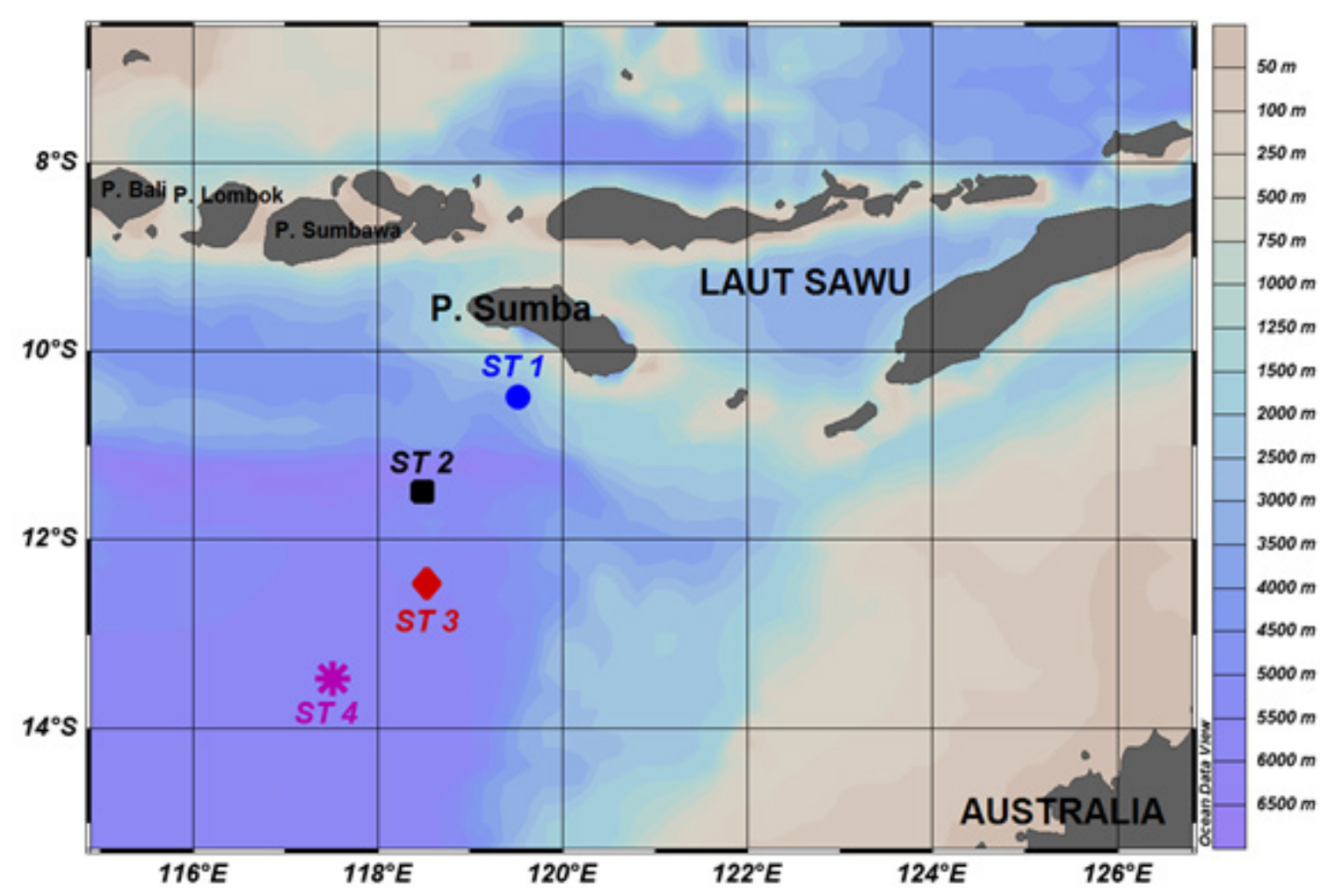

Gambar 1. Peta titik lokasi kajian / stasiun CTD, perairan P. Sumba - NTT.

Figure 1. Map of study point / CTD stations, Sumba Island Water - NTT. 


\section{HASIL DAN PEMBAHASAN}

\section{Sebaran Suhu Air Laut}

Pada musim timur reanalysis bulan Agustus tahun 2013, kisaran suhu pada ST 1 adalah $26,49-3,4{ }^{\circ} \mathrm{C}$, pada ST 2 kisaran $26,40-3,41^{\circ} \mathrm{C}$, ST 3 sebesar $26,37-3,40^{\circ} \mathrm{C}$, dan ST 4 sebesar $26,29-3,40^{\circ} \mathrm{C}$ (Gambar 2). Sebaran secara melintang suhu perairan dekat laut lepas (sisi kanan atau $400 \mathrm{Km})$ sedikit lebih rendah $\left(26,29^{\circ} \mathrm{C}\right)$ dari pada perairan dekat dengan pantai (sisi kiri atau $0 \mathrm{Km}$ ) $\left(26,49^{\circ} \mathrm{C}\right)$. Kisaran nilai suhu pada musim timur ini cukup rendah, sebagai akibat dari posisi matahari yang berada pada daratan Asia dan kondisi dingin terjadi pada daratan Australia. Secara umum, perairan Indonesia memiliki kisaran suhu permukaan laut sebesar 28$31^{\circ} \mathrm{C}$ (Nontji, 2007). Di musim penghujan, suhu udara di sekitar Australia lebih dingin dari pada daratan Asia (Nontji, 2007). Juga sangat terlihat dari sebaran SPL pada sekitar perairan P. Sumba yaitu dengan kisaran $26,4-26,49^{\circ} \mathrm{C}$ (Gambar 2). Sebagai pembanding data SPL pada musim timur (reanalysis bulan Agustus ) tahun 2013, juga dapat terlihat kisaran yang hampir sama kondisi pada musim timur pada tahun-tahun sebelumnya (2009). Kondisi SPL yang cukup rendah tersebut sering berkaitan dengan kejadian upwelling, dimana suhu kisaran $26-27^{\circ} \mathrm{C}$ diidentifikasi sebagai kejadian upwelling sedang dan $<26^{\circ} \mathrm{C}$ upwelling kuat, serta kondisi lemah pada kisaran SPL $>26^{\circ} \mathrm{C}$ (Kunarso et al., 2005). Hal ini dapat menguatkan dugaan bahwa pada perairan P. Sumba saat musim timur tersebut dapat terjadi upwelling. Kejadian upwelling merupakan mekanisme transport massa air yang terjadi dari kedalaman tertentu menuju permukaan, diduga membawa serta unsur hara yang berguna dan sebagai lokasi yang banyak ikan. Selain itu, kriteria daerah potensi ikan memiliki rentang suhu antara $20-29,34^{\circ} \mathrm{C}$
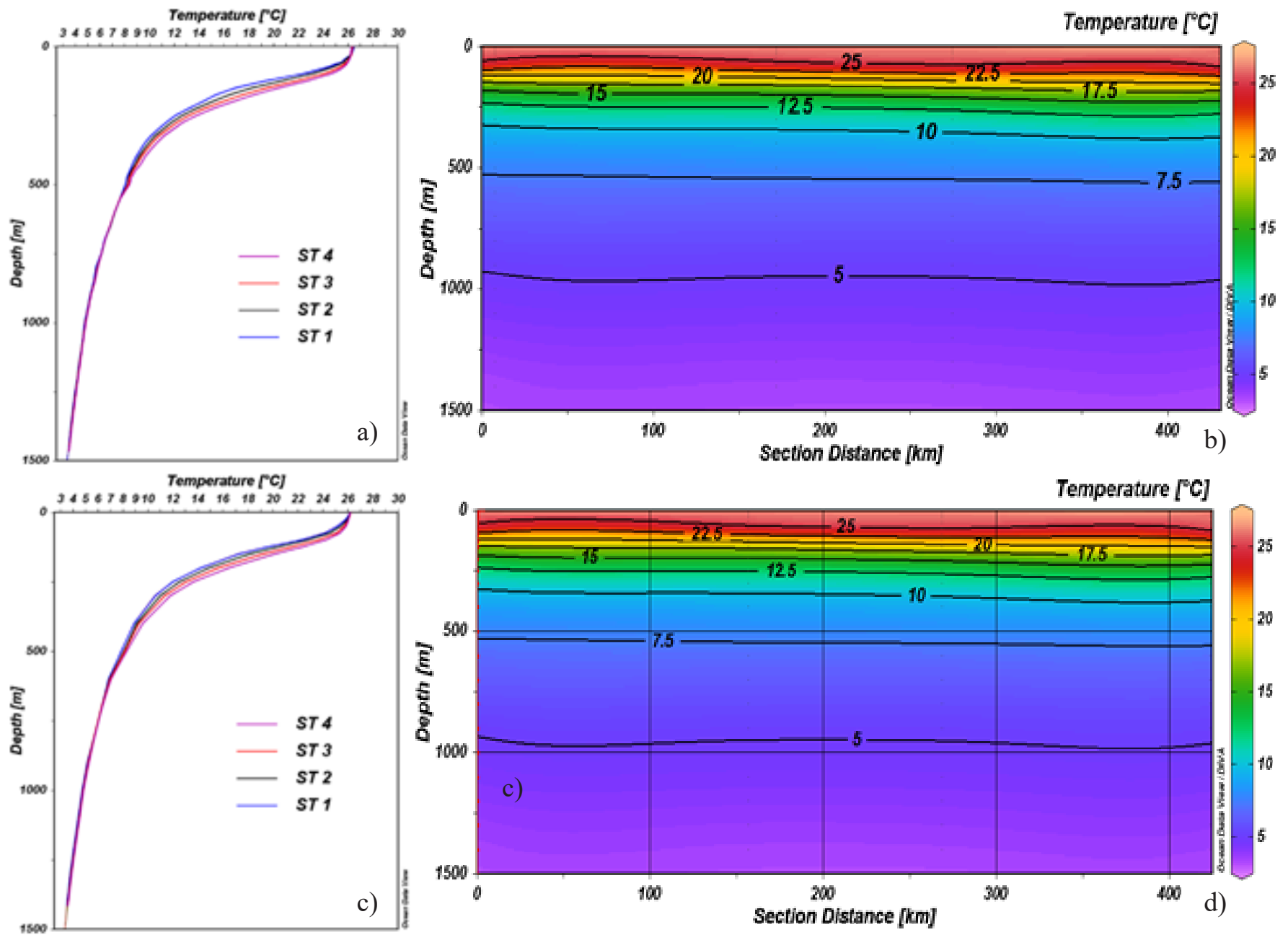

Gambar 2. Sebaran menegak dan melintang suhu perairan P. Sumba pada musim timur (reanalysis bulan Agustus):

a) dan b) tahun 2013, c) dan d) tahun 2009

Figure 2. a. Distribution of temperature uprigh and transverse at Sumba Island in east season (August): a) and b) 2013, c) and d) 2009 
Tabel 1. Konsentrasi rataan klorofil-a selama rentang tahun 2003 - 2015. (Hestiningsih et al., 2017)

Table 1. The average concentration of chlorophyll-a for the period 2003 - 2015. (Hestiningsih et al., 2017)

\begin{tabular}{|c|c|c|c|c|c|c|c|c|c|c|c|c|}
\hline Bulan & Jan & Feb & Mar & April & Mei & Juni & Juli & Agust & Sept & Okt & Nov & Des \\
\hline $\begin{array}{l}\text { Klorofil-a } \\
\left(\mathrm{mg} / \mathrm{m}^{3}\right)\end{array}$ & 0,21183 & 0,20615 & 0,22985 & 0,24124 & 0,33311 & 0,41301 & 0,37439 & 0,30406 & 0,2233 & 0,2087 & 0,1989 & 0,17691 \\
\hline
\end{tabular}

(Zahroh \& Sukojo, 2016). Parameter SPL dan klorofil-a merupakan faktor yang mempengaruhi perikanan ataupun berkaitan dengan wilayah penangkapan ikan (Tangke et al., 2015), dimana indikasi nilai klorofil-a menjadi lebih tinggi karena unsur hara yang terangkut ke atas permukaan oleh fenomena upwelling tersebut. Kondisi tersebut semakin diperkuat lagi dengan nilai konsentrasi klorofil-a di sekitar perairan NTT (Tabel

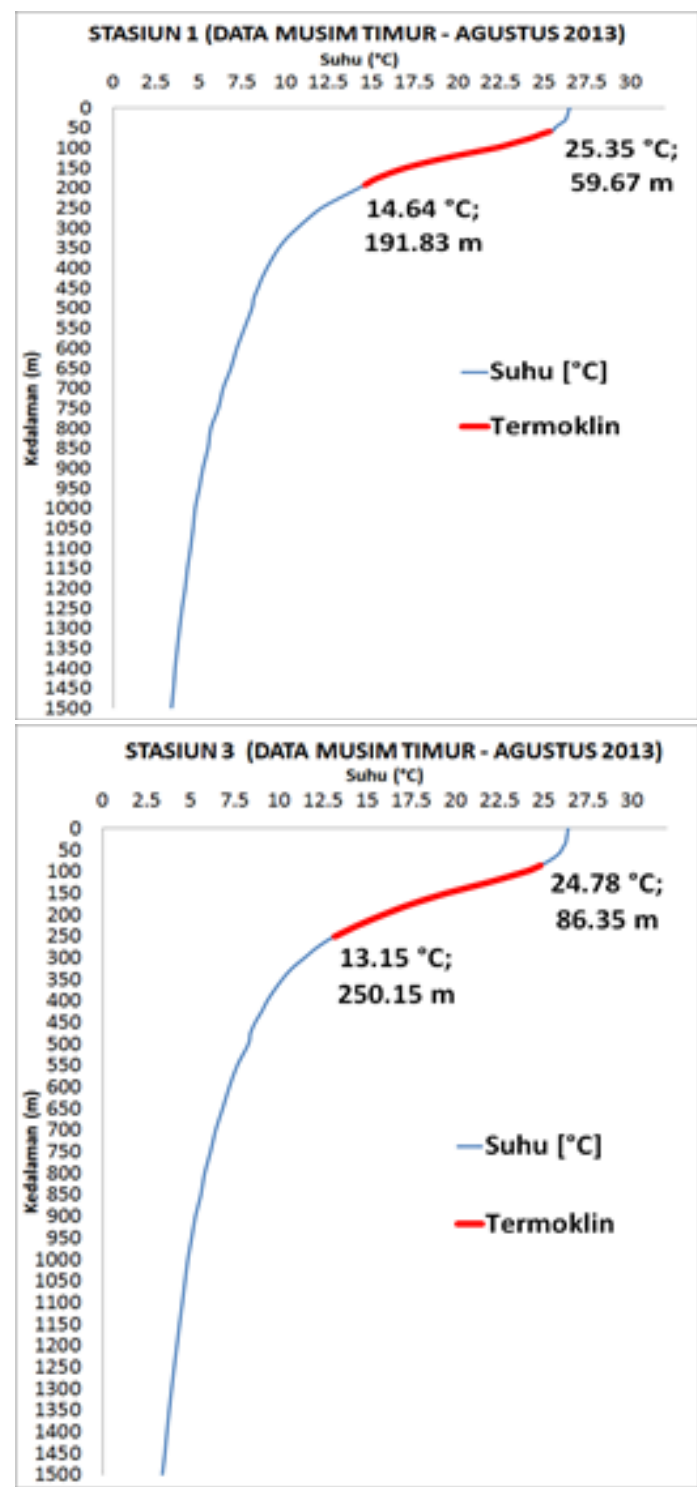

1), pada saat musim timur (JJA) kisaran nilai klorofil-a lebih tinggi yaitu sekitar $0,3-0,4 \mathrm{mg} / \mathrm{m}^{3}$ (Hestiningsih et al., 2017).

Secara umum hasil yang diperoleh dari sebaran menegak suhu di perairan barat daya P. Sumba adalah terdapat tiga zona berdasarkan kedalaman. Pada bagian permukaan hingga kedalaman tertentu

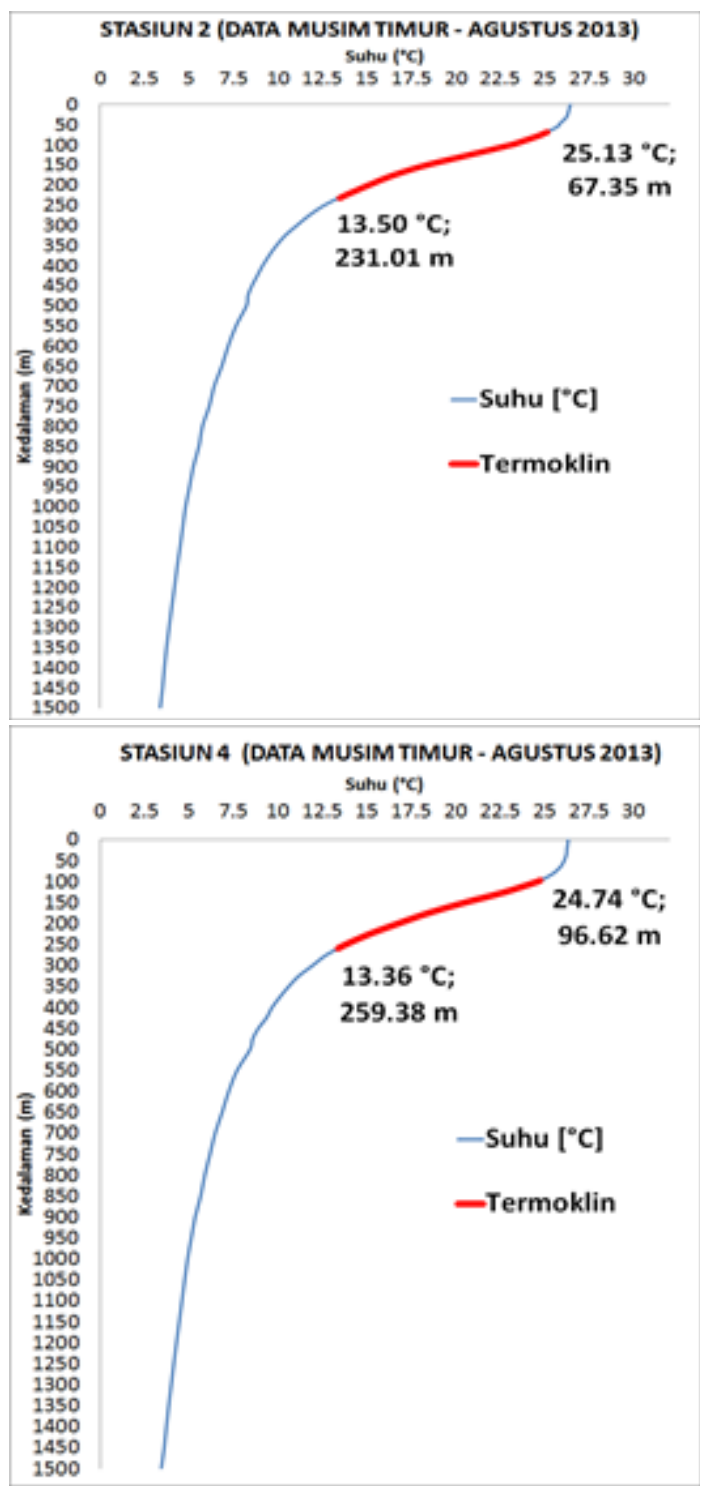

Gambar 3. Zonasi perairan berdasarkan kedalaman pada musim timur bulan Agustus 2013 (lapisan tercampur, termoklin, dan bawah).

Figure 3. Water zonation based on depth in east season (mix layer, thermocline, and under layer). 
Tabel 2. Lapisan termoklin perairan P. Sumba pada musim timur (reanalysis bulan Agustus) tahun 2013

Table 2. Thermocline layer at Sumba Island on east season (2013, August)

\begin{tabular}{lllll}
\hline ST & batas atas $(\mathbf{m})$ & \multicolumn{2}{l}{ batas bawah $(\mathbf{m})$ ketebalan lapisan $(\mathbf{m})$} & perubahan suhu $\boldsymbol{\Delta t}\left({ }^{\circ} \mathbf{C}\right)$ \\
\hline 1 & 59,67 & 191,83 & 132,16 & 10,71 \\
2 & 67,35 & 231,01 & 163,66 & 11,63 \\
3 & 86,35 & 250,15 & 163,80 & 11,63 \\
4 & 96,62 & 259,38 & 162,75 & 11,37 \\
\hline
\end{tabular}

merupakan zona tercampur, kemudian terlihat adanya lapisan termoklin, yang mana terjadi penurunan suhu yang sangat drastis terhadap kedalaman, serta lapisan dalam yang mendeskripsikan kondisi suhu air laut tidak banyak mengalami perubahan. Pembagian zona perairan berdasarkan kedalaman pada musim timur (reanalysis bulan Agustus) 2013 dapat terlihat dari Gambar 3. Lapisan tercampur pada ST 1 terdapat pada permukaan laut hingga kedalaman 59,67 m dengan kisaran suhu sebesar $25,59-26,49^{\circ} \mathrm{C}$, ST 2 pada kedalaman mencapai $67,35 \mathrm{~m}$ dengan kisaran suhu $25,26-26,4^{\circ} \mathrm{C}$, ST 3 terdapat hingga kedalaman $86.35 \mathrm{~m}$, kisaran suhu $24,86-26,37^{\circ} \mathrm{C}$, serta ST 4 pada kedalaman mencapai 96,62 m dengan kisaran suhu $24,83-26,29^{\circ} \mathrm{C}$. Kedalaman lapisan tercampur ini cukup dalam, terutama bagian laut lepas. Hal ini dapat terjadi diperkirakan karena pengadukan massa air terutama oleh angin (Gambar 4) lebih besar terjadi pada musim timur tersebut. Dapat terlihat juga secara jelas dari grafik windrose angin (Gambar 5), bahwa kecepatan angin kisaran 5,2 - 8,1 m/s pada saat musim timur (Gambar 5.b) terjadi lebih banyak dari kejadian angin pada saat musim barat (Gambar 5.a). Pola yang terbentuk pada lapisan tercampur (permukaan) adalah bahwa ketebalan lapisan tercampur semakin tebal/ dalam pada bagian laut lepas dibandingkan dengan perairan dekat pesisir. Pada kisaran bulan Juni, Juli, dan Agustus, karena pusat tekanan udara tinggi berada di atas Benua Australia menyebabkan angin berhembus dari tenggara menuju barat laut menuju pusat tekanan udara rendah di atas Benua Asia (Wyrtki, 1961). Akibatnya pengadukan tentu lebih besar terjadi pada perairan yang dekat dengan daratan Australia. Dalam kondisi bersamaan, berbanding terbalik dengan kondisi lapisan tercampur, lapisan termoklin pada musim timur menjadi lebih tipis.

Kisaran batas bawah dan batas atas lapisan termoklin pada musim timur dapat terlihat pada Tabel 2. Lapisan termoklin terjadi pada kedalaman 59,67-191,83 m (ketebalan $132,16 \mathrm{~m}$ ) dengan perubahan suhu $25,35^{\circ} \mathrm{C}$ menjadi $14,64^{\circ} \mathrm{C}\left(\Delta \mathrm{t}=10,71^{\circ} \mathrm{C}\right)$. Pada ST 2, lapisan termoklin terjadi pada kedalaman 67,35-231,01 m (ketebalan $163,66 \mathrm{~m}$ ) dengan perubahan suhu $25,13{ }^{\circ} \mathrm{C}$ menjadi $13,50^{\circ} \mathrm{C}\left(\Delta \mathrm{t}=11,63{ }^{\circ} \mathrm{C}\right)$. Pada ST 3, lapisan termoklin terjadi pada kedalaman 86,35-250,15 m (ketebalan $163,80 \mathrm{~m}$ ) dengan perubahan suhu $24,78^{\circ} \mathrm{C}$ menjadi $13,15^{\circ} \mathrm{C}\left(\Delta \mathrm{t}=11,63^{\circ} \mathrm{C}\right)$. Pada ST 4, lapisan termoklin terjadi pada kedalaman 96,62 - 259,38 m (ketebalan $162,75 \mathrm{~m}$ ) dengan perubahan suhu $24,74^{\circ} \mathrm{C}$

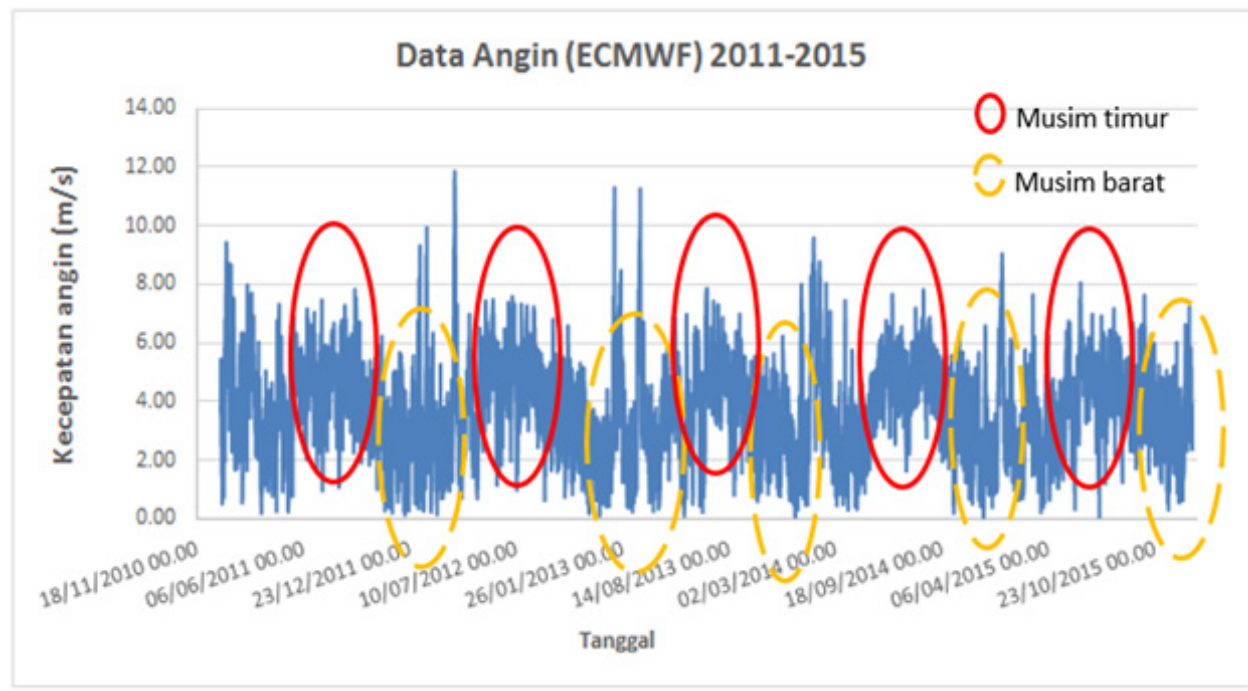

Gambar 4. Kondisi besaran kecepatan angin di sekitar P. Sumba selama 5 tahun (2011-2015) Figure 4. Wind velocity in Sumba Island arround while 5 years (2011-2015) 
a)

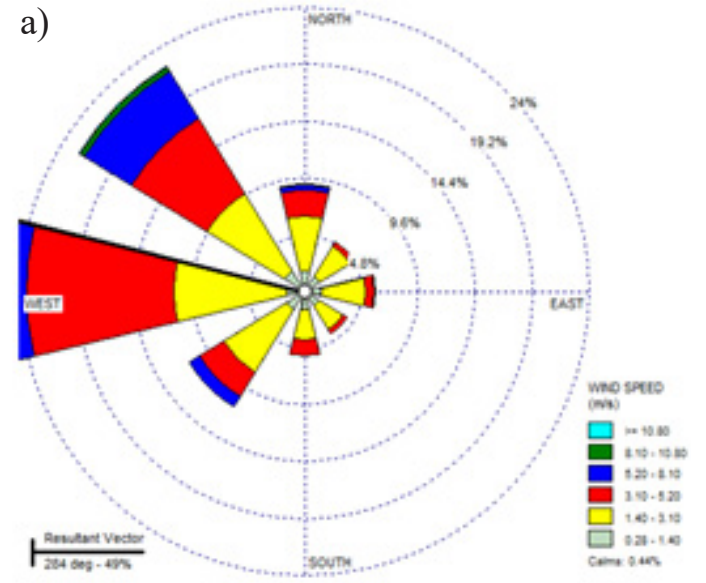

b)

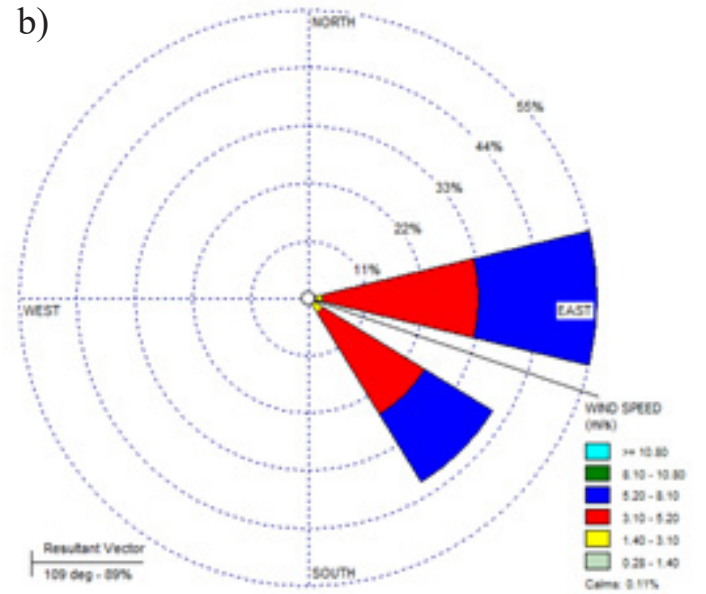

Gambar 5. Windrose parameter angin di sekitar P. Sumba selama 5 tahun (2011-2015):

a. Musim barat dan b. Musim timur.

Figure 5. Windrose of wind parameter at Sumba Island arround while 5 years (2011-2015 ): a. West seasonal and b. East seanonal.

menjadi $13,36^{\circ} \mathrm{C}\left(\Delta \mathrm{t}=11,37^{\circ} \mathrm{C}\right.$.

Secara keseluruhan pada perairan P. Sumba lapisan termoklin terjadi pada kedalaman 59,67 m sampai 259,38 m (Tabel 2). Pada perairan Indonesia bagian timur, kedalaman lapisan termoklin lebih dalam dari pada perairan Indonesia bagian barat. Pada perairan Indonesia bagian timur, lapisan termoklin dapat mencapai kedalaman 174 - 233 m (Lana et al., 2017). Lapisan dalam perairan P. Sumba selama musim timur secara umum berada pada kedalaman di bawah $200 \mathrm{~m}$. Pada ST 1 lapisan dalam memiliki kisaran suhu 14,28 $-3,4{ }^{\circ} \mathrm{C}$ terdapat pada kedalaman $>192 \mathrm{~m}$, pada ST 2 dengan kisaran suhu $12,63-3,4^{\circ} \mathrm{C}$ pada kedalaman $>$ $231 \mathrm{~m}$, pada TS 3 berkisar $12,20-3,4^{\circ} \mathrm{C}$ pada kedalaman $>250 \mathrm{~m}$, dan ST 4 dengan kisaran suhu $12,68-3,4{ }^{\circ} \mathrm{C}$ pada kedalaman $260 \mathrm{~m}$. Perubahan suhu perairan pada lapisan dalam hanya terjadi cukup kecil sekitar $\pm 8^{\circ} \mathrm{C}$, pada kedalaman antara 200 dan 1500 m (Gambar 3).

Nilai suhu sedikit berbeda terjadi pada musim barat (reanalysis bulan Februari) tahun 2013 terutama pada lapisan permukaan. Dapat terlihat bahwa kisaran suhu lapisan permukaan pada musim barat lebih tinggi dibandingkan pada saat musim timur. Pada musim barat kisaran suhu dari permukaan hingga kedalaman tertentu pada ST 1 adalah $29,04-3,41^{\circ} \mathrm{C}$, pada ST 2 kisaran $28,93-3,42^{\circ} \mathrm{C}$, ST 3 sebesar $28,87-3,42^{\circ} \mathrm{C}$, dan ST 4 sebesar $28,74-3,42^{\circ} \mathrm{C}$ (Gambar 6). Untuk kisaran SPL, pada ST 1 adalah 27,97 - 29,04 ${ }^{\circ} \mathrm{C}$, pada ST 2 kisaran 27,94 - 28,93 ${ }^{\circ} \mathrm{C}$, ST 3 sebesar 27,98 $28,87{ }^{\circ} \mathrm{C}$, dan ST 4 sebesar $27,89-28,74{ }^{\circ} \mathrm{C}$. Kondisi suhu permukaan laut pada musim barat ini secara umum memiliki nilai lebih tinggi sebesar $\pm 2{ }^{\circ} \mathrm{C}$ jika dibandingkan saat musim timur yang hanya memiliki suhu permukaan perairan paling tinggi sebesar $26,49^{\circ} \mathrm{C}$. Pada kisaran bulan Desember - Februari (musim barat), musim dingin terjadi pada belahan bumi bagian utara dan sebaliknya kejadian musim panas pada belahan bumi bagian selatan. Hal ini terjadi karena posisi matahari yang berada di belahan bumi bagian selatan, sehingga bagian selatan menjadi lebih hangat. Hal ini juga diperkuat dari hasil pergerakan angin pada musim barat pada Perairan Indonesia serta kejadian SPL seperti Gambar 7 (Qu et al., 2005). Bahkan kisaran SPL di sekitar lokasi kajian dapat mencapai $29-30^{\circ} \mathrm{C}$. Sebaran melintang SPL dari perairan dekat pesisir pantai (ST 1) masih lebih tinggi dari pada wilayah perairan jauh ke arah laut lepas (ST 4).

Hasil pelapisan massa air dari parameter suhu perairan pada musim barat juga terdapat 3 zona, yaitu zona tercampur (permukaan), lapisan termoklin, dan lapisan dalam (Gambar 8). Dapat terlihat secara jelas, bahwa lapisan tercampur (permukaan) saat musim barat ini sangat tipis, berkisar hingga kedalaman 45,6 - 49,19 $\mathrm{m}$ (Tabel 3), cukup berbeda signifikan dibandingkan dengan lapisan tercampur saat musim timur (sekitar $>60 \mathrm{~m}$ ), lapisan termoklin sedikit lebih tebal dengan kisaran 174,70 - 185,70 m.

\section{Sebaran Salinitas Laut}

Kisaran nilai salinitas pada musim timur (reanalysis bulan Agustus) tahun 2013 secara menegak dari permukaan sampai kedalaman $1500 \mathrm{~m}$ adalah ST 1 $(34,05$ - 34,67 psu), ST 2 (34,07 - 34,67 psu), ST 3 $(34,08-34,67 \mathrm{psu})$, dan ST 4 (34,11 - 34,70 psu). Hasil sebaran menegak salinitas air laut (Gambar 9) tersebut 

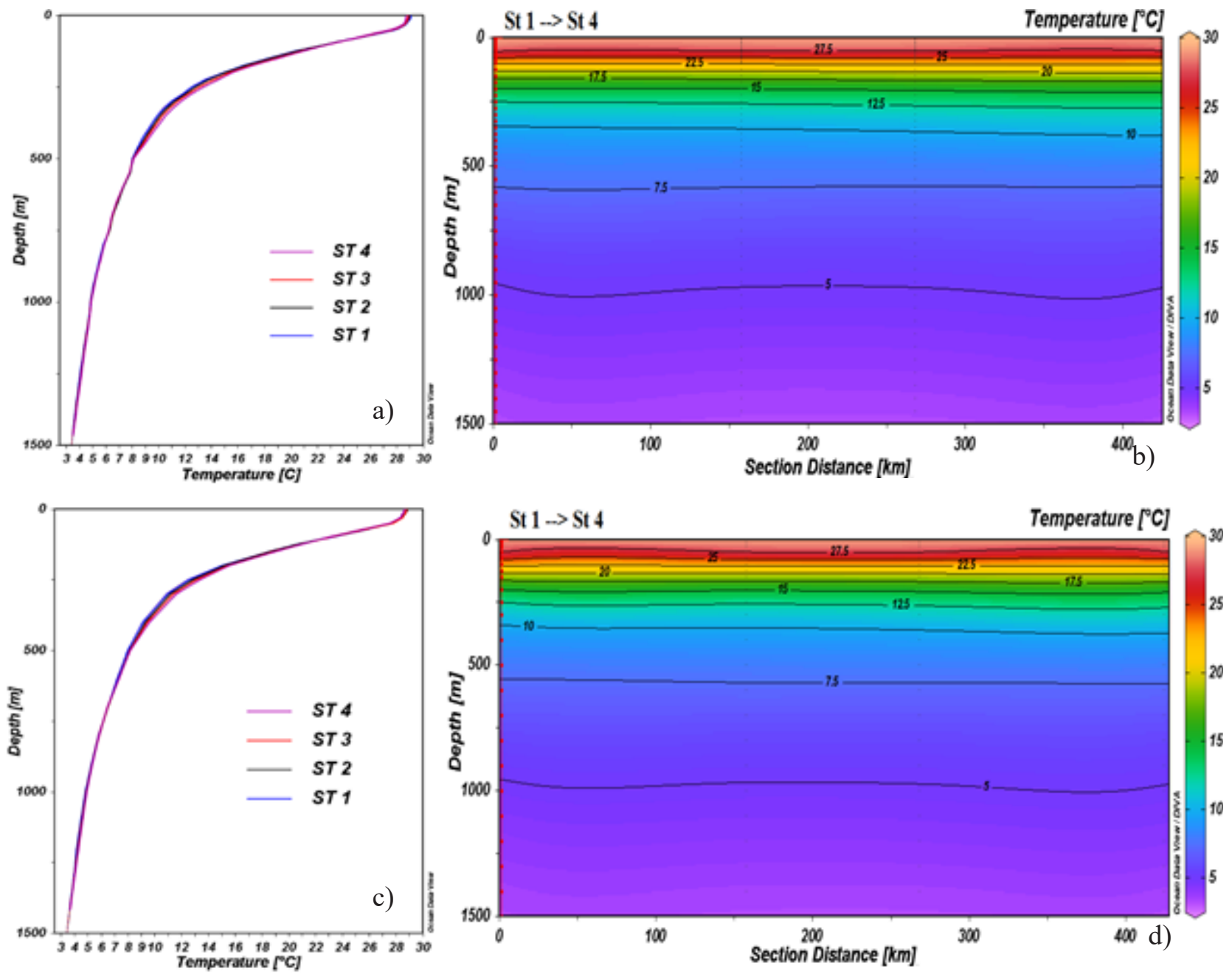

Gambar 6. Sebaran menegak dan melintang suhu perairan P. Sumba pada musim barat (reanalysis bulan Februari), a) dan b) tahun 2013 dan c) dan d) tahun 2009.

Figure 6. Distribution of temperature uprigh at Sumba Island in east season (Februari), a) 2013 and b) 2009.

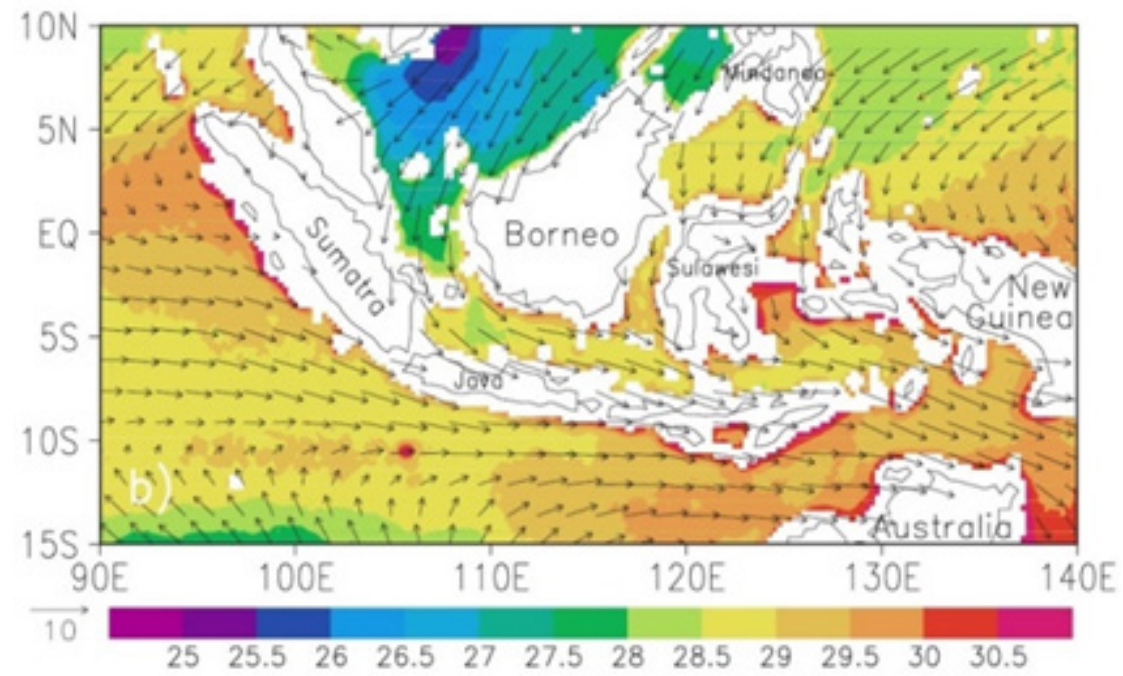

Gambar 7 . Kondisi angin muson barat di Indonesia. (Qu et al., 2005)

Figure 7. West monsoon in Indonesia 

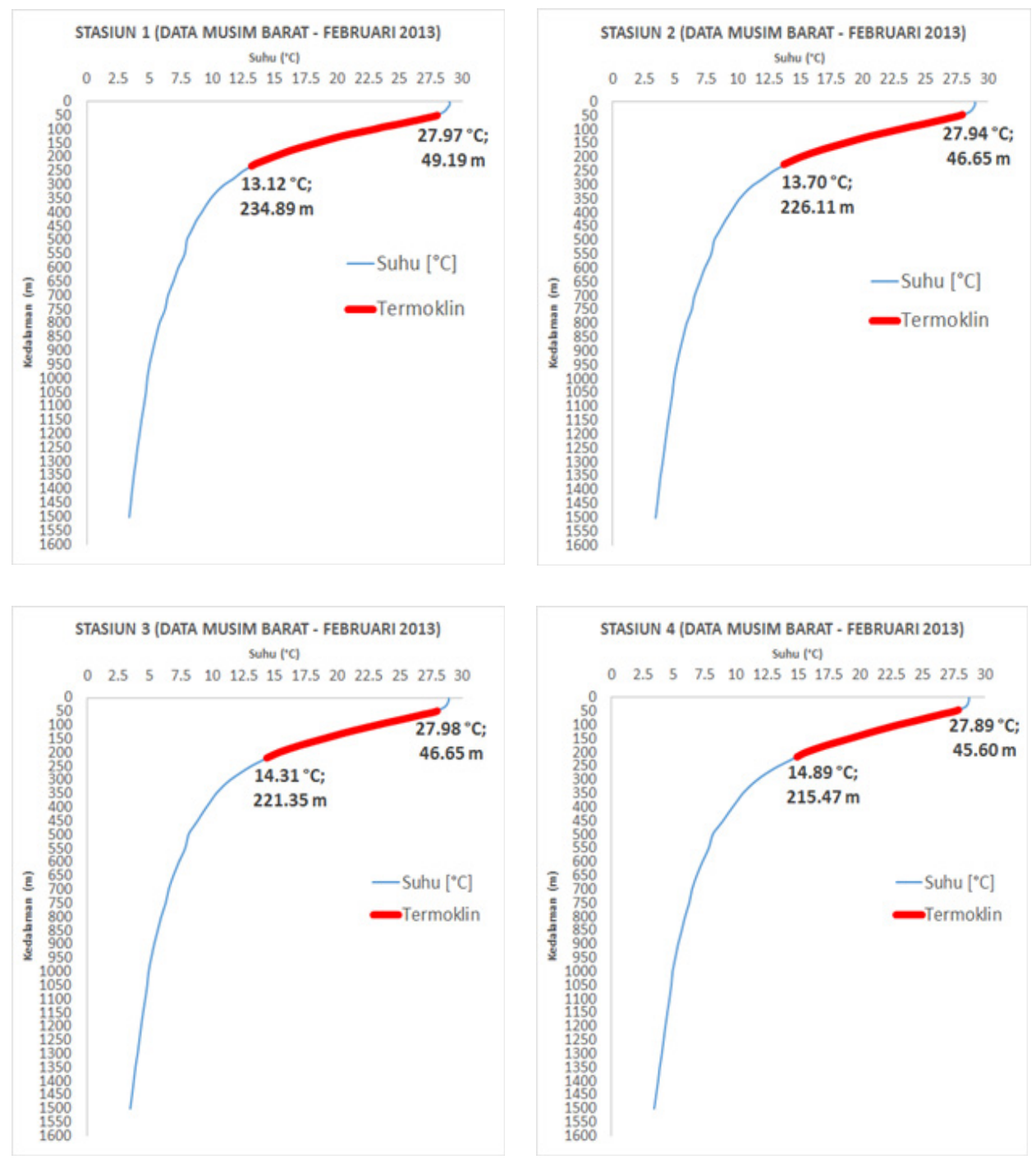

Gambar 8. Zonasi perairan berdasarkan kedalaman pada musim barat bulan Februari 2013 (lapisan tercampur, termoklin, dan bawah).

Figure 8. Water zonation based on depth in west season (mix layer, thermocline, and under layer).

Tabel 3. Lapisan termoklin perairan P. Sumba pada musim barat (reanalysis bulan Februari) tahun 2013

Table 3. Thermocline layer at Sumba Island on west season (2013, February)

\begin{tabular}{|c|c|c|c|c|}
\hline ST & batas atas $(m)$ & batas bawah $(\mathrm{m})$ & ketebalan lapisan (m) & perubahan suhu $\Delta t\left({ }^{\circ} \mathrm{C}\right)$ \\
\hline 1 & 49,19 & 234,89 & 185,70 & 14,85 \\
\hline 2 & 46,65 & 226,11 & 179,45 & 14,24 \\
\hline 3 & 46,65 & 221,35 & 174,70 & 13,66 \\
\hline 4 & 45,60 & 215,47 & 169,88 & 12,99 \\
\hline
\end{tabular}

menunjukkan kondisi salinitas meningkat secara umum terhadap pertambahan kedalaman. Kondisi tersebut terjadi hingga kedalaman $\pm 500 \mathrm{~m}$, kemudian diikuti dengan kondisi salinitas yang relatif tidak berubah (hanya perubahan yang sangat kecil). Kebalikan dari kondisi suhu air laut yang lebih hangat (tinggi) berada pada permukaan, dan terus berkurang seiring dengan bertambahnya kedalaman. Pada lapisan permukaan, sebaran salinitas juga banyak dipengaruhi pengadukan oleh angin, sehingga terdapat lapisan tercampur hingga kedalaman mencapai $50 \mathrm{~m}$ Bahkan menurut Nontji (2007), lapisan homogen parameter salinitas akibat pengadukan oleh angin ini dapat mencapai 50 - 70 $\mathrm{m}$. Kisaran nilai salinitas pada musim timur ini cukup tinggi, sebagai akibat mendapat pengaruh aliran dari Samudera pasifik (Nontji 2007) sehingga memiliki 

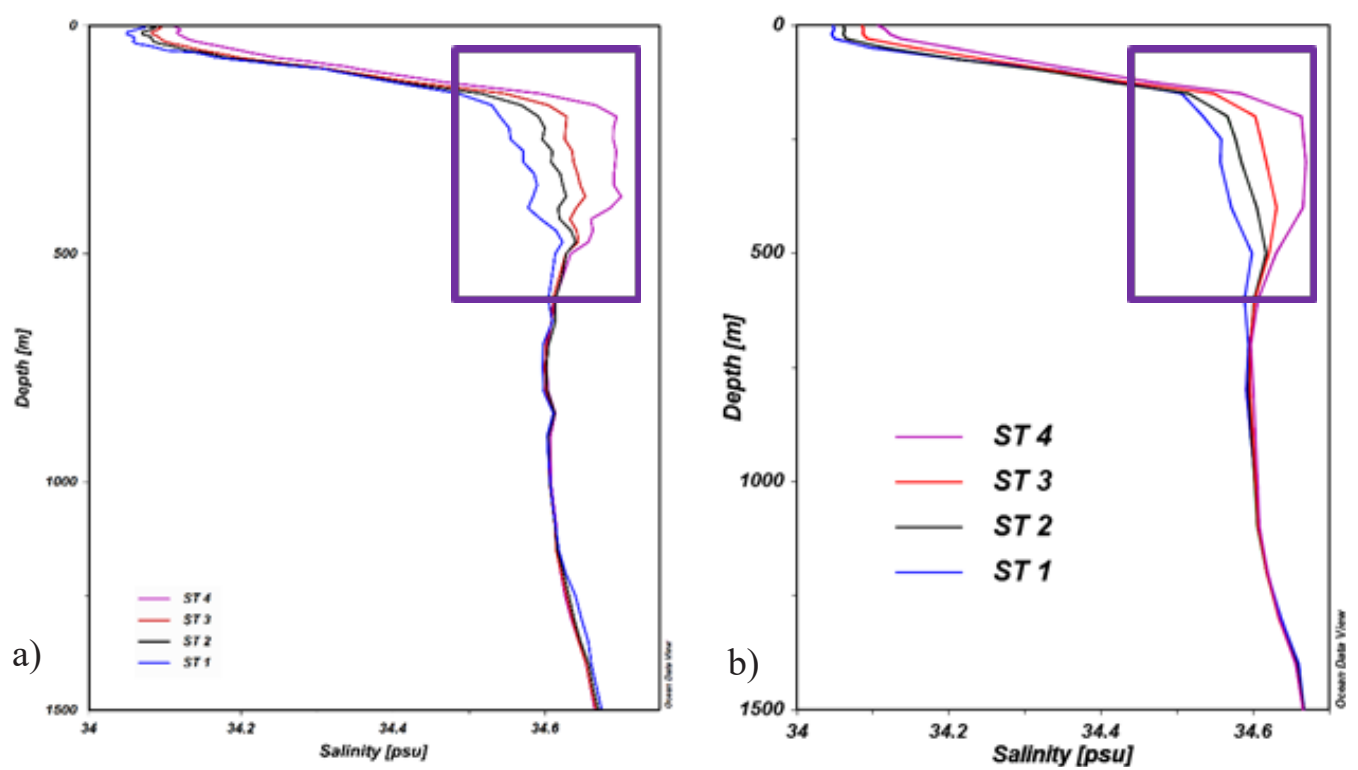

Gambar 9. Sebaran menegak salinitas perairan P. Sumba pada musim timur (reanalysis bulan Agustus), a) tahun 2013 dan b) tahun 2009.

Figure 9. Distribution of salinity uprigh at Sumba Island in east season (August), a) 2013 and b) 2009.

nilai salinitas $>34$ psu. Pada sekitar lapisan termoklin terlihat nilai maksimum salinitas dengan kisaran 34,634,7 psu, terjadi secara umum pada setiap titik stasiun CTD (Gambar 10).

Pada sebaran melintang salinitas (Gambar 10), terlihat stratifikasi salinitas di kolom perairan antara perairan pesisir dan laut lepas. Titik ST 1 yang berada pada bagian kiri, terjadi stratifikasi salinitas cukup lebar dengan nilai 34,6 psu hingga pada kedalaman 500 $\mathrm{m}$, sedangkan pada titik stasiun dekat laut lepas (ST 3 dan 4) pada nilai salinitas yang sama hanya pada kedalaman sekitar $200 \mathrm{~m}$. Hal tersebut dapat terjadi diduga salah satunya akibat aktivitas di darat dan masukan air sungai pada perairan tersebut. Hal ini berbanding lurus dengan terjadinya pengadukan massa air pada lapisan termoklin, menjadikan kisaran kedalaman tersebut memiliki kandungan nutrien yang tinggi, sehingga membuat nilai salinitas juga tinggi pada kedalaman termoklin tersebut. Beberapa faktor yang dapat mempengaruhi salinitas rendah pada permukaan laut adalah evaporasi, presipitasi, masukan air tawar, dan perubahan arus akibat musim (Nontji, 2007; Kaharuddin, 2013).

Sebaran parameter salinitas perairan di P. Sumba pada

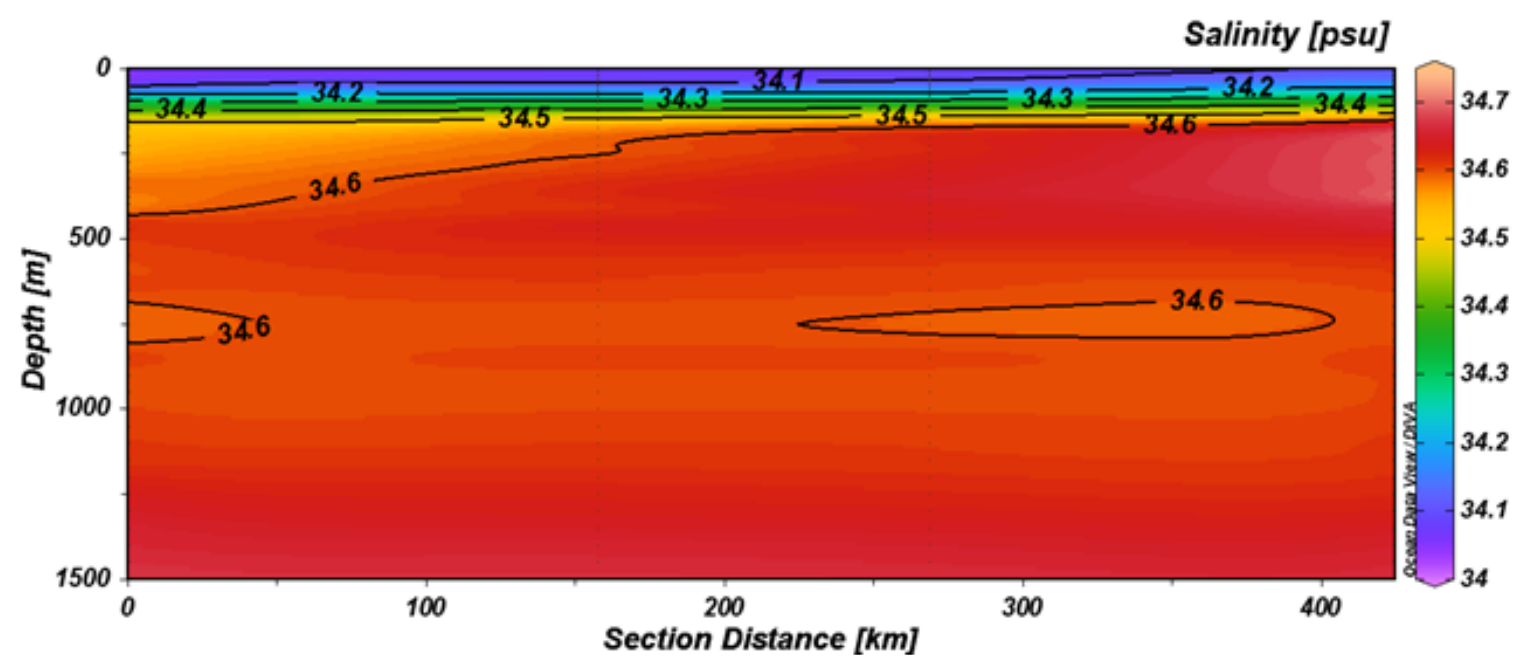

Gambar 10. Sebaran melintang salinitas perairan P. Sumba pada musim timur, reanalysis bulan Agustus 2013 Figure 10. Distribution of sea salinity transverse at Sumba Island water in east season, reanalysis in August 2013. 

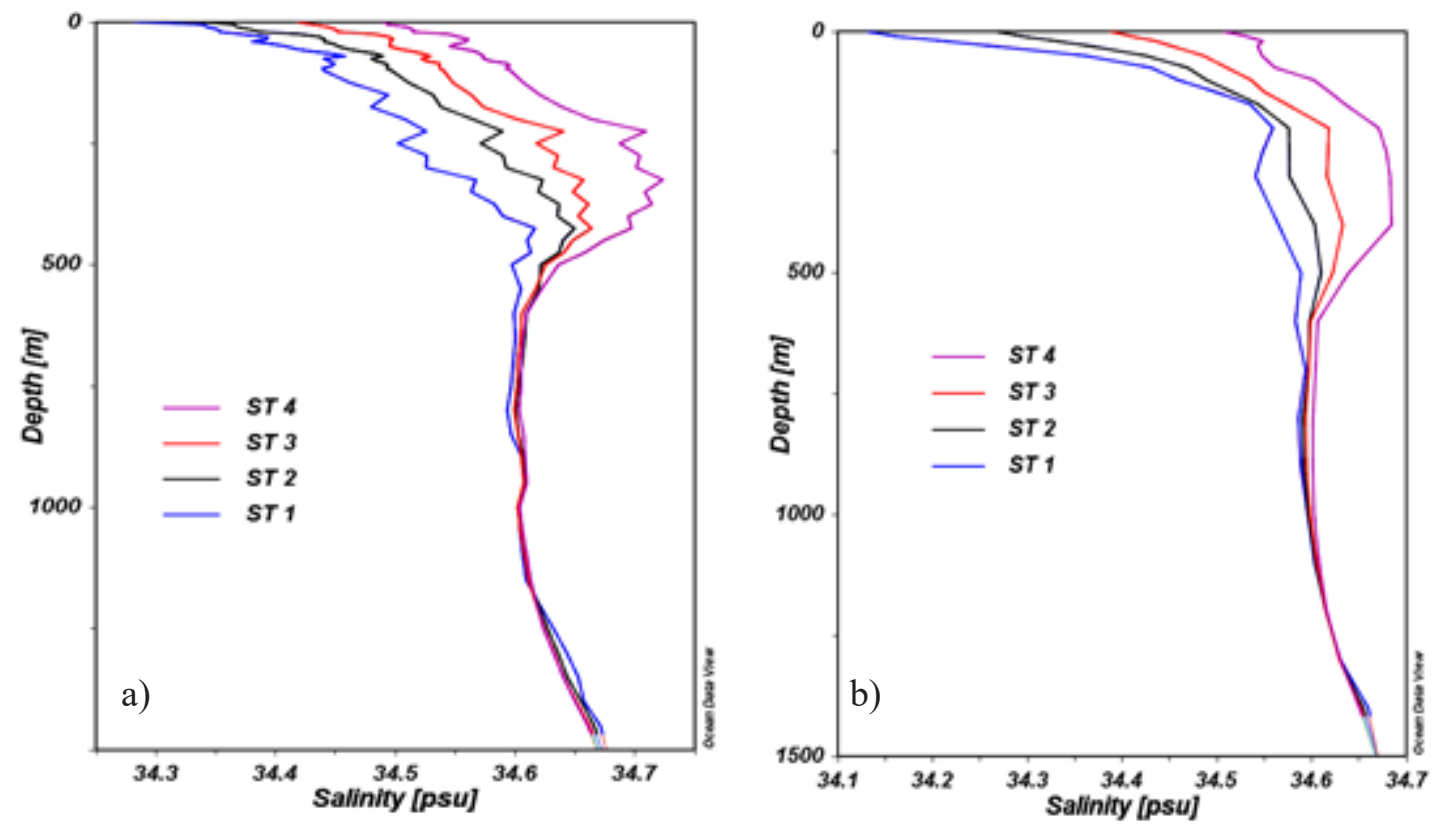

Gambar 11. Sebaran menegak salinitas perairan P. Sumba pada musim barat (bulan Februari), a) tahun 2013 dan b) tahun 2009 .

Figure 11. Distribution of salinity uprigh at Sumba Island in west season (February), a) 2013 and b) 2009.

musim barat memiliki kisaran sedikit berbeda (lebih tinggi) bila dibandingkan saat musim timur. Kisaran nilai salinitas pada musim barat (reanalysis bulan Februari) tahun 2013 secara menegak dari permukaan sampai kedalaman $1500 \mathrm{~m}$ adalah ST $1(34,28-34,68$ psu), ST 2 (34,34 - 34,67 psu), ST $3(34,42-34,67$ psu), dan ST 4 (34,49 - 34,72 psu) (Gambar 11). Namun secara umum, kondisi nilai salinitas tersebut

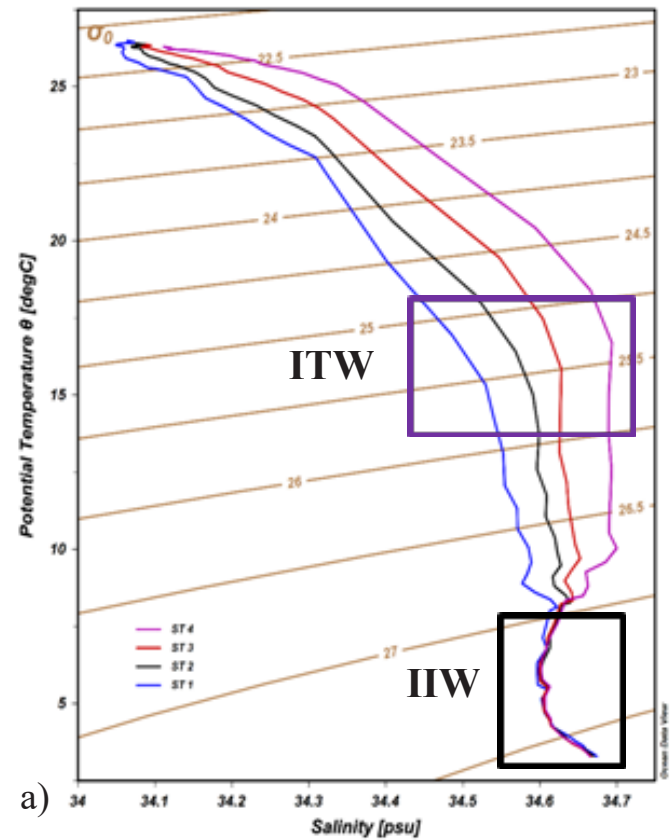

masih memiliki kisaran yang umum bagi perairan laut dengan nilai $>34$ psu, sebagai akibat mendapat pengaruh aliran dari Samudera pasifik (Nontji, 2007).

Diagram T-S biasa digunakan untuk menentukan karakteristik massa air suatu perairan laut, yang dapat menjelaskan asal usul dari massa air tersebut. Karakteristik massa air adalah badan air yang relatif

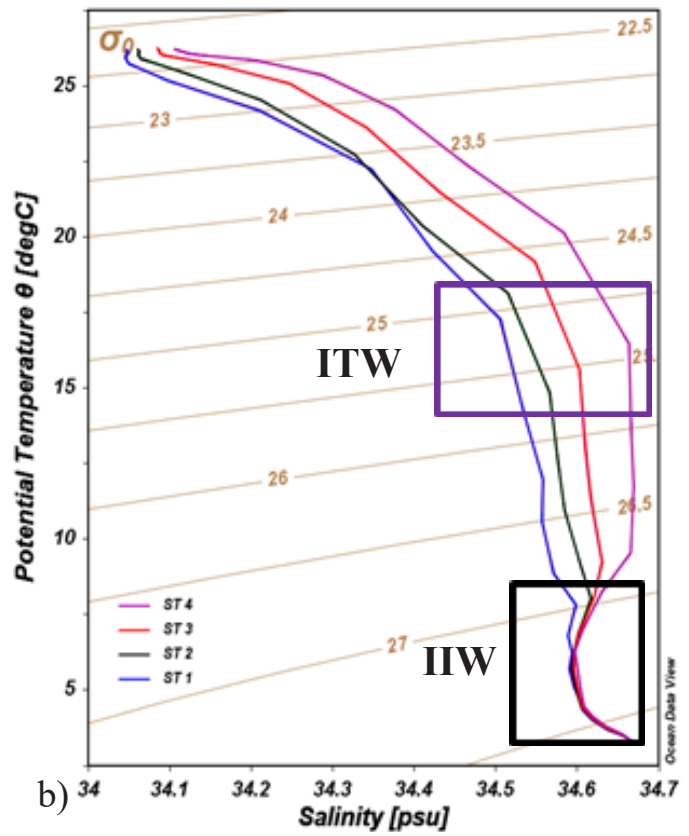

Gambar 12 . Diagram TS perairan Pulau Sumba pada musim timur (bulan Agustus), a) tahun 2013 dan b) tahun 2009.

Figure 12. TS diagrams at Sumba Island water in east season (August), a) 2013 and b) 2009. 

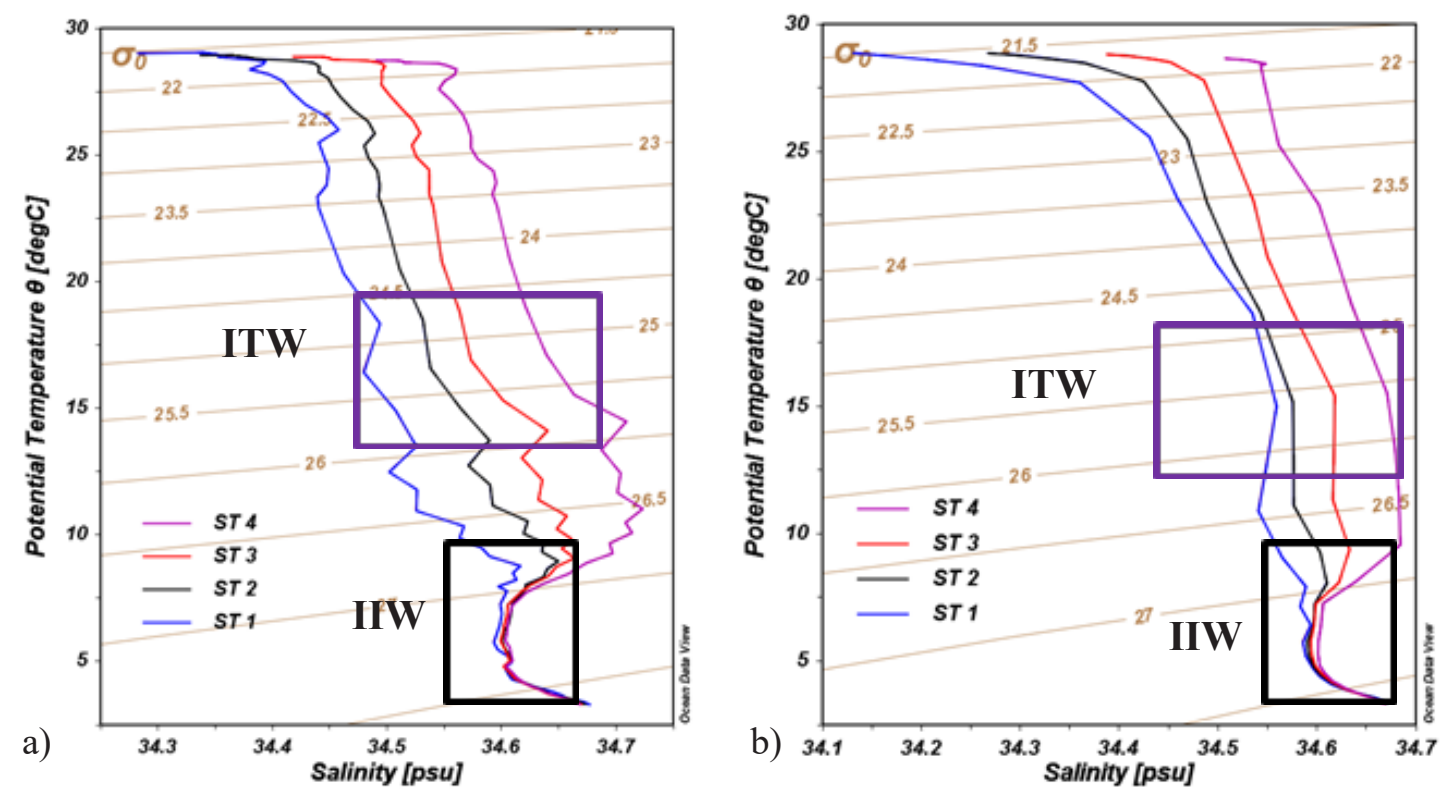

Gambar 13 . Diagram TS perairan Pulau Sumba pada musim barat (bulan Februari), a) tahun 2013 dan b) tahun 2009.

Figure 13. TS diagrams at Sumba Island water in west season (February), a) 2013 and b) 2009.

homogen dan dapat digambarkan dengan karakteristik yang dimilikinya (Agustinus. et al. 2016). Jenis massa air yang terlihat dari diagram T-S (Gambar 12), pada musim timur bulan Agustus 2013, pada ST 1 - ST 4 bahwa karakteristik massa air diduga dipengaruhi oleh jenis North Pacific Subtropical Water (NPSW), memiliki salinitas mencapai $34,65 \mathrm{psu}$, suhu $15{ }^{\circ} \mathrm{C}$, serta densitas sebesar 25,5 - 26. Kemudian saat di Samudera Hindia dan di lokasi kajian, massa air tersebut bertransformasi menjadi jenis ITW segar pada lokasi antara Australia dan Indonesia pada kedalaman antara permukaan dan $400 \mathrm{~m}$ (Wijffels et al., 2002). Pada kondisi suhu dan densitas yang sedikit berbeda, aliran ARLINDO kemungkinan dapat menyebabkan perubahan karakteristik terhadap salinitas menjadi lebih rendah (Wijffels et al., 2002; You, 2003; Harvianto et al., 2015), terlihat pada ST 1 - ST 2 hingga menjadikan nilai salinitas sebesar 34,5 - 34,6 psu dan suhu $12-14{ }^{\circ} \mathrm{C}$, serta ST 3 dan ST 4 dengan rentang salinitas $34,65-34,7$ psu, suhu 12 $-14{ }^{\circ} \mathrm{C}$. Massa air NPSW merupakan jalur massa air dari Pasifik yang bergerak ke arah timur melalui Selat Ombai, Flores dan Laut Sawu (Sprintall et al., 2009; Purwandana, 2013), sehingga keluar juga melewati perairan P. Sumba, terdapat pada kedalaman air laut sekitar $250-500 \mathrm{~m}$, massa air ini terdapat di sekitar lapisan termoklin. Karakteristik massa air yang terjadi pada lapisan permukaan diduga dapat disebabkan oleh angin muson tenggara (SEM/Southeast Moonson), karena pada waktu tersebut merupakan puncak dari muson tenggara. Selain itu diduga juga dipengaruhi oleh ARLINDO, yang bergerak memasuki Laut Sawu dan melintas pada perairan P. Sumba. Nilai salinitas permukaan tersebut berkisar 34,1 - 34,55 psu, dan densitas berkisar 21,5. Massa air yang dominan dari Pasifik yang melewati pintu keluar ARLINDO mengalami pengenceran akibat intrusi sungai dan curah hujan yang tinggi (Kaharuddin, 2013).

Nilai salinitas maksimum sebesar 34,7 psu yang terjadi pada kedalaman $500 \mathrm{~m}$ dan terdapat pada stasiun 4 . Pada titik dan kedalaman tersebut nilai suhu mencapai $10^{\circ} \mathrm{C}$. Pada lapisan dalam, terlihat kecenderungan yang sama dari massa air antar stasiun. Terdapat kesamaan nilai diagram T-S pada setiap stasiun, terjadi pada kedalaman $>600 \mathrm{~m}$, dengan nilai salinitas 34,6-34,7 psu, suhu antara $3-7^{\circ} \mathrm{C}$ dan densitas sebesar $27-27,7$. Karakteristik massa air ini berada pada lapisan dalam sekitar 750 - 1500 m. Karakteristik massa air dengan komposisi suhu dan salinitas serta densitas tersebut dapat tergolong dengan jenis Indonesian Intermediate Water (IIW) (Fieux et al., 1996; Wijffels et al., 2002; Emery, 2003). Pada kondisi musim barat, tidak terjadi perubahan nilai karakteristik dari massa air yang melewati perairan P. Sumba tersebut (Gambar 13).

\section{KESIMPULAN DAN SARAN}

Karakteristik suhu air laut pada perairan barat daya P. Sumba musim timur tergolong rendah. Suhu di perairan lepas pantai sedikit lebih rendah dari pada perairan pesisir. Hal ini diperkirakan karena tiupan 
angin di lepas pantai lebih dingin karena dekat dengan daratan Australia. Hal ini berbanding terbalik dengan sebaran salinitas, dimana salinitas dekat laut lepas sedikit lebih tinggi dari pada perairan pesisir. Hal ini diperkirakan karena dekat dengan perairan pesisir penyucian air tawar lebih tinggi berasal dari daratan dan kegiatan masyarakat, salah satunya dapat terjadi akibat aliran Sungai Kambaniru. Berbeda pada musim barat, SPL lebih hangat dan memiliki lapisan tercampur (permukaan) lebih tipis. Karakteristik massa air pada perairan P. Sumba dipengaruhi oleh North Pacific Subtropical Water (NPSW) bertransformasi menjadi ITW segar dan pada lapisan di bawah termoklin diduga massa air Indonesian Intermediate Water (IIW).

\section{UCAPAN TERIMA KASIH}

Ucapan terimakasih kami ucapkan kepada semia pihak atas terlaksananya seluruh kegiatan penelitian sampai selesai.

\section{DAFTAR PUSTAKA}

[ECMWF] Eropean Centre For Medium-Range Weather Forcasts. 2019. Data Arah dan Kecepatan Angin (Lokasi Perairan Pulau Sumba). [accessed 2019 Jul 15]. http://apps.ecmwf.int/datasets/.

[ODV] Ocean Data View. 2009. World Ocean Atlas 2009. Ocean Data View. [accessed 2019 Aug 8]. https://odv. awi.de/data/ocean/world-ocean-atlas-2009/.

[ODV] Ocean Data View. 2013. World Ocean Atlas 2013. Ocean Data View. [accessed 2018 Sep 14]. http://odv. awi.de/data/ocean/worlt-ocean-atlas-2013/.

Agustinus., Dwi, R. T., Pandoe, W. W., \& Riyadi, N. (2016). Studi Karakteristik Massa Air Untuk Menentukan Shadow Zone di Selat Makassar. J Chart Datum. 2:69-78

Aken, H.M. Van., Punjanan, J., \& Saimima, S. (1988). Physical Aspects of the Flushing of the East Indonesian Basins. Netherlands J Sea Res. 22(4):315339. doi:10.1016/0077-7579(88)90003-8.

Aldrian, E. (2008). Meteorologi Laut Indonesia. Jakarta (ID): Badan Meteorologi dan Geofisika.

Emery, W. J. (2003). OCEAN CIRCULATION (Water Types and Water Masses). Boulder (US): Elsivier Science Ltd.

Fieux, M., Andrie, C., Charriaud, E., Ilahude, A. G., Metzl, N., Molcard, R., \& Swallow, J. C. (1996). Hydrological and Chlorofluoromethane Measurements of the Indonesian Throughflow Entering the Indian Ocean. $J$ Geophys Res. 101(C5):12,433-12,454. doi:01480227/96/96JC-00207.

Gaol, J. L., Arhatin, R. E., \& Ling, M. M. (2014). Pemetaan Suhu Permukaan Laut Dari Satelit Di Perairan Indonesia Untuk Mendukung “One Map Policy.” In:
Seminar Nasional Penginderaan Jauh 2014. p. $433-$ 442.

Harvianto, L., Parengkuan, M., Koropitan, A. F., \& Agustiadi ,T. (2015). Analisis Diagram T-S Berdasarkan Parameter Oseanografis di Perairan Selat Lombok. Surya Octag Interdiscip J Technol. 1(1):103-119.

Hasanudin, M. (1998). Arus Lintas Indonesia (ARLINDO). J Oseana. XXIII(2):1-9.

Hestiningsih, Prasetyo Y, Sasmito B, Wirasatriya A. 2017. Identifikasi Kawasan Upwelling Berdasarkan Variabilitas Klorofil-A, Suhu Permukaan Laut Dari Data Citra Aqua Modis Tahun 2003-2015 dan Arus (Studi Kasus: Perairan Nusa Tenggara Timur). J Geod UNDIP. 6(1):189-198.

Ilahude, A., \& Gordon, A. L. (1994). Water Masses of the Indonesian Seas Through flow. In: IOC-WESTPAC Third International Scientific Symposium. Bali Indonesia.

Kaharuddin. (2013). Analisis Karakteristik Massa Air pada Lapisan Termoklin di Selatan Dewakang Sill Selat Makassar. J Pertan Terpadu. 1(1):191-207.

Kunarso, Ningsih, N. S., \& Supangat, A. (2005). Karakteristik Upwelling di Sepanjang Perairan Selatan NTT Hingga Barat Sumatera. J Ilmu Kelaut UNDIP. 10(1):17-23.

Lana, A. B., Kurniawati, N., Purba, N. P., \& Syamsuddin, M. L. (2017). Thermocline Layers Depth and Thickness in Indonesian Waters when Southeast Monsoon. $J$ Omni-Akuatika. 13(2):65-72.

Nontji, A. (2007). Laut Nusantara. Fifth Ed. Jakarta: Djambatan.

Pond, S., \& Pickard, G. L. (1983). Introductory Dynamical Oceanography. Edisi 2. Canada: Department of Oceanography - University of British Columbia.

Purba, M. (2007). Dinamika Perairan Selatan P. Jawa - P. Sumbawa Saat Muson Tenggara. J Ilmu Kelaut dan Perikan TORANI. 17(2):140-150.

Purwandana, A. (2013). Kajian Percampuran Vertikal Massa Air dan Manfaatnya. J Oseana. 38(3):9-22.

Qu, T., Du, Y., Strachan, J., Meyers, G., \& Slingo, J. (2005). Sea Surface Temperature and Its Variability In The Indoneisan Region. J Oceanogr. 18(4):50-61.

Siregar, S. N., Sari, L. P., Purba, N. P., Pranowo, W.S., \& Syamsuddin, M. L. (2017). Pertukaran Massa Air di Laut Jawa Terhadap Periodisitas Monsun dan Arlindo pada Tahun 2015. J Depik Unsyiah. 6(1):4459. doi:10.13170/depik.6.1.5523.

Sprintall, J., Wijffels, S. E., Molcard, R., \& Jaya, I. (2009). Direct Estimates of the Indonesian Throughflow Entering the Indian Ocean: 2004-2006. J Geophys Res-Ocean.

Suhana, M. P., Utama, F. G., Putra, A. P., Zibar, Z., Paputungan, M. S, Erawan, M. T. F., \& Kolibongso, D. (2018). Pola dan Karakteristik Sebaran Medan Massa, Medan Tekanan dan Arus Geostropik Perairan Selatan Jawa. J Din Marit. 6(2):20-25.

Suteja, Y., Purba, M., \& Atmadipoera, A. S. (2015). Percampuran Turbulen di Selat Ombai. J Ilmu dan 
Teknol Kelaut Trop. 7(1):71-82.

Tangke, U., Karuwal, J. C., Zainuddin, M., \& Mallawa A. (2015). Sebaran Suhu Permukaan Laut dan Klorofil-A Pengaruhnya Terhadap Hasil Tangkapan Yellowfin Tuna (Thunnus Albacares) di Perairan Laut Halmahera Bagian Selatan. J IPTEKS PSP. 2(3):248260.

Wijaya, R., Setiawan, F., \& Fitriani, S. D. (2011). Kajian Fenomena Arlindo di Laut Seram dan Kaitannya dengan Perubahan Iklim Global. In: Seminar Internasional Kelautan. Denpasar - Bali (ID): Balai Riset Observasi Kelautan.

Wijffels, S., Sprintall, J., Fieux, M., \& Bray, N. (2002). The JADE and WOCE I10/IR6 Throughtflow Sections in the Southeast Indian Ocean. Part 1: Water Mass Distribution and Variability. Deep Sea Res II. 49:1341-1362. doi:10.1016/S0967-0645(01)001552.

Wyrtki, K. (1961). NAGA REPORT (Scientific Results of Marine Investigations of the South China Sea and the Gulf of Thailand 1959-1961). Second Ed. California (USA): Scripps Institution of Oceanography - The University of California.

Wyrtki, K. (1962). The upwelling in the region between Java and Australia during the south-east monsoon. Aust $J$ Mar Freshw Res. 13:217-225.

You, Y. (2003). The Pathway and Circulation of North Pacific Intermediate Water. J Geophys Res Lett. 30(24):10-110-4. doi:10.1029/2003GL018561.

Zahroh, L., \& Sukojo, B. M. (2016). Analisis Suhu Permukaan Laut untuk Penentuan Daerah Potensi Ikan Menggunakan Citra Satelit Modis Level 1B (Studi Kasus: Selat Bali). J Tek ITS. 5(2):A846-A849. 